Short Communication

Human and Medical Genetics

\title{
A clinical report of the massive CAG repeat expansion in spinocerebellar ataxia type 2: Severe onset in a Mexican child and review previous cases
}

José Sánchez-Corona ${ }^{1}$, Sergio Alberto Ramirez-Garcia² ${ }^{2}$ iD, Gema Castañeda-Cisneros ${ }^{3}$ iD, Susan Andrea Gutiérrez-Rubio $^{4}$ (iD) Víctor Volpini ${ }^{5}$, Diana M. Sánchez-Garcia ${ }^{6}$, José Elías García-Ortiz ${ }^{7}$ iD and Diana García-Cruz ${ }^{8}$ iD

${ }^{1}$ Instituto Mexicano del Seguro Social - IMSS, Centro de Investigaciones Biomédicas de Occidente - CMNO, División de Medicina Molecular, Jalisco, Mexico.

${ }^{2}$ Universidad de la Sierra Sur, Instituto de Nutrición y de Investigaciones sobre la Salud Pública, Oaxaca, Mexico.

${ }^{3}$ Instituto Mexicano del Seguro Social - IMSS, UMAE Hospital de Especialidades, Centro Médico de Occidente, Guadalajara, Jalisco, Mexico.

${ }^{4}$ Universidad de Guadalajara, Centro Universitario de Ciencias de la Salud - CUCS, Departamento de Fisiología, Guadalajara, Jalisco, Mexico.

${ }^{5}$ Institut d'Investigació Biomédica de Bellvitge - IDIBELL, Centro de Diagnóstico Genético Molecular, Barcelona, Spain.

${ }^{6}$ ITESO, Universidad Jesuita de Guadalajara, Guadalajara, Jalisco, Mexico.

${ }^{7}$ Instituto Mexicano del Seguro Social - IMSS, Centro de Investigación Biomédica de Occidente - CIBO, División de Genética, Guadalajara, Jalisco, Mexico.

${ }^{8}$ Universidad de Guadalajara, Centro Universitario de Ciencias de la Salud - CUCS, Instituto de Genética Humana "Enrique Corona Rivera", Jalisco, Mexico.

\begin{abstract}
The spinocerebellar ataxia type 2 is a neurodegenerative disease with autosomal dominant inheritance; clinically characterized by progressive cerebellar ataxia, slow ocular saccades, nystagmus, ophthalmoplegia, dysarthria, dysphagia, cognitive deterioration, mild dementia, peripheral neuropathy. Infantile onset is a rare presentation that only has been reported in four instances in the literature. In the present work a boy aged 5 years 7 months was studied due to horizontal gaze-evoked nystagmus, without saccades, ataxic gait, dysarthria, dysphagia, dysmetria, generalized spasticity mainly pelvic, bilateral Babinsky. The mother aged 27 years-old presented progressive cerebellar ataxia, dysarthria, dysmetria, dysdiadochokinesis, limb ataxia and olivopontocerebellar atrophy. The molecular analysis was made by identifying the expansion repeats in tandem by long PCR to analyze the repeats in the ATXN2 gene. We found an extreme CAG expansion repeats of $\sim 884$ repeats in the child. We describe a Mexican child affected by SCA2 with an infantile onset, associated with a high number of CAG repeats previously no reported and anticipation phenomenon.
\end{abstract}

Keywords: Ataxin-2 gene, anticipation phenomenon, autosomal dominant, spinocerebellar ataxia type 2, triplet expansion repeat.

Received: October 12, 2019; Accepted: June 25, 2020.

Spinocerebellar ataxia type 2 (SCA2) (MIM ID $\# 183090)$ is an autosomal dominant disorder with progressive cerebellar ataxia, slow ocular and dysmetric vertical saccades, gaze-evoked nystagmus, supranuclear ophthalmoplegia, dysarthria, dysphagia, rigidity, spasticity, dysmetria and dysdiadochokinesis, bradykinesia,

Send correspondence to Diana García Cruz. Universidad de Guadalajara, Centro Universitario de Ciencias de la Salud - CUCS, Instituto de Genética Humana "Enrique Corona Rivera", Edificio p, segundo nivel, Sierra Mojada 950, CP 70900, Lomas de Independencia, Guadalajara, Jalisco, Mexico. E-mail: dianagarcr@hotmail.com. myoclonus, cognitive deterioration, mild dementia, dopamine-responsive parkinsonism, peripheral neuropathy and olivopontocerebellar atrophy (Choudhry et al., 2001). SCA2 has a global prevalence of 1:35,000 individuals, is caused by (CAG)n abnormal long expansions in the ataxin-2 gene (ATXN2, 601517) (gene map locus 12q24.12), encoding a polyglutamine tract (polyQ) in the mutant protein which represent the large majority.

SCA2 is the most prevalent of the polyQ ataxias in Cuba, India, Mexico, and Southern Italy, and the second most prevalent worldwide, accounting for $15 \%$ of all cases (Antenora et al., 2017). An infantile onset is an uncommon 
occurrence presentation with only nine reports in the literature and is associated with extremely large CAG expansions (range 100-200 repeats). On the other hand, there are severe infantile cases with expansions between 50-70 repeats, sometimes is related with interruption CTG or CAA as occurs in adults with SCA2 and amyotrophic lateral sclerosis, which also leads to instability of ATXN2 mRNA (Choudhry et al., 2001; Antenora et al., 2017), and meiotic instability a general feature of SCA2 without a familial history (Babovic et al., 1998; Mao et al., 2002; Moretti et al., 2004; Dirik et al., 2007; Abdel and Zaki, 2008; Paciorkowski et al., 2011; Di Fabio et al., 2012; Vinther-Jensen et al., 2013; Singh et al., 2014). However, cases with infantile SCA2 are explain by these features; there are childhood onset cases reported with mosaicism in germ cells such as spermatozoa with larger expanded alleles more than in peripheral blood cells (Moretti et al., 2004; Dirik et al., 2007; Abdel and Zaki, 2008; Vinther-Jensen et al., 2013).

The most frequent signs in infantile onset are developmental delay, visual impairment usually dependent on retinitis pigmentosa or optic atrophy, hypotonia, seizures with infantile spasms or myoclonic seizures, facial dysmorphism, dystonic features and early death (Tables 1 and 2) (Singh et al., 2014; Antenora et al., 2017). Brain MRI scans showed extreme cerebellar and brainstem atrophy, but also different degrees of supratentorial atrophy, ventricular enlargement, and white matter signal abnormalities probably attributable to dysmyelination and/or delayed myelination (Singh et al., 2014; Antenora et al., 2017). The aim of this report is to present the clinical findings and molecular studies in a Mexican child with familial SCA2 with extremely large CAG expansion repeats, and a literature review of clinical and molecular findings in early-onset cases with SCA2.

The clinical findings in the index case, a boy aged $5 \mathrm{yr}$ 7 mo (Figure 1A), was the product of the first pregnancy complicated by hyperemesis during the first trimester, delivery was by cesarean section due to macrosomia. Since birth the patient presented feeding difficulties due to dysphagia that persists at this time; at 3 months of age nystagmus was present. Psychomotor development, at 12 months he began to walk with evident ataxic gait. When he started speaking at 2-3 years of age, he presented dysarthria, at this moment he has progression of all the symptomatology, poor coordination, walking difficulty, incontinence (he never had sphincter control) and he continues with dysphagia. At physical examination he presented horizontal gaze-evoked nystagmus, without saccades, ataxic gait, dysarthria, dysphagia, dysmetria, generalized spasticity mainly pelvic, bilateral Babinsky. CT brain scan revealed mild pontine atrophy, moderate cerebellar atrophy (Table 2) (Figure 1B,C).

Family data: Mother aged 27 years similarly affected, clinical symptomatology began at 7 years of age with walking and speech difficulties. At 10 years of age she started with seizures, controlled for 5 years. Currently presents ataxia, dysarthria, dysmetria, dysdiadochokinesia, ataxic gait with olivopontocerebellar atrophy. Father aged 30-year-old neurologically healthy. Two maternal aunts of
30 and 23 years and the maternal grandmother (age of onset $40 \mathrm{yr}$ ), were similarly affected. Mother with molecular analysis positive to SCA2 with a genotype 22/49 CAG expansion repeats and father with normal range or expansion repeats.

Genomic DNA was extracted from peripheral blood leukocytes using the Gene Catcher Kit (Invitrogen) of the index case. The analysis of the ataxin-2 gene was performed by long PCR using a pair of oligonucleotides flanking the repeated CAGs. The sequence of the oligonucleotides was as follows: FWP1 5'-GGGCCCCTCACCATGTCG-3'; and RWP 5'-CGGGCTTGCGGACATTGG-3' ('Sigma Aldrich). PCR was carried out in a total volume of $10 \mu \mathrm{l}$ containing $100 \mathrm{ng}$ of human DNA, $0.4 \mu \mathrm{M}$ of each oligonucleotide, $200 \mu \mathrm{M}$ of each dNTP; $0.6 \mu$ of the $10 \mathrm{x}$ reaction buffer (Roche Diagnostics $\mathrm{GmbH}$ ), $2 \mathrm{mM} \mathrm{MgCl} 2$ (Roche Diagnostics), $0.5 \mathrm{U}$ of the enzyme Taq DNA polymerase (Roche Diagnostics $\mathrm{GmbH}$ ) and 10\% DMSO (Sigma-Aldrich) (Magaña et al., 2008; Flores-Alvarado et al., 2016). The amplification program consisted of 28 cycles, including denaturation at $96{ }^{\circ} \mathrm{C}$ for $60 \mathrm{~s}$, hybridization at 59 ${ }^{\circ} \mathrm{C}$ for $30 \mathrm{~s}$ and polymerization at $72{ }^{\circ} \mathrm{C}$ for $60 \mathrm{~s}$ (Magaña $e t$ al., 2008; Flores-Alvarado et al., 2016).

The PCR product was mixed with deionized formamide and denatured in water bath for seven minutes. Then it was placed on ice frappe for five minutes, and subjected by electrophoresis on $10 \%$ polyacrylamide gels (PAGE, 29:1). From the PCR products, were made a dilution $1: 5$ to apply $5 \mathrm{~mL}$ in the respective lane. PAGE gel was run at 150 volts, during 6.25 hours (Magaña et al., 2008); and subsequently stained with a solution containing; $0.1 \mathrm{~g}$ silver nitrate, $0.5 \mathrm{~mL}$ of acetic acid and $10 \mathrm{~mL}$ of ethanol graduated at $100 \mathrm{~mL}$ (12). The development solution used in the PAGE gels contained $3 \%$ sodium hydroxide with $270 \mu \mathrm{L}$ of $37 \%$ formaldehyde graduated to $100 \mathrm{ml}$ (Flores-Alvarado et al., 2016).

The amplified fragment of $130 \mathrm{bp}$ corresponds to a normal allele of $22 \mathrm{CAG}$ repeats. The normal range is between 13-31 CAG repeats and in affected cases greater than 32 repeats (Guzmán-López et al., 2018). In the PCR-PAGE denaturing assay (Figure 2) the first lane is a molecular weight marker of $100 \mathrm{bp}$, the second lane is the white control PCR which appears white, without amplified product, in lanes 4 and 6 is the sample 124 with a DNA dilution of 1:5, there is a band of $130 \mathrm{bp}$ and another band at $2 \mathrm{~kb}$ that was calculated as $2,652 \mathrm{bp}$ which generates the genotype 22/ 884 repeats; in lanes 3 and 7 is the sample 125 with a DNA dilution of 1:5, a band of $130 \mathrm{bp}$ is observed and in lane 5 there is a negative control sample for the trinucleotide expansion repeat. Thus, with these considerations, the index case presented a normal allele of $22 \mathrm{CAG}$ repeats, and an allelic variant of $\sim 884 \mathrm{CAG}$ expansion repeats $(2,652 \mathrm{bp})$, being carrier of the genotype $22 / \sim 884$. This result was corroborated by the RED (Repeat Expansion Detection) method in the IDIBELL Center of Molecular Diagnosis; showing a higher penetrance allele of $2600 \mathrm{bp}$.

The present case is the first report of an index case with autosomal dominant SCA2 of neonatal presentation due to 
Table 1 - Previous cases review of infantile-onset SCA2.

\begin{tabular}{|c|c|c|c|c|c|}
\hline Reference & Main findings & $\begin{array}{c}\text { Age of } \\
\text { onset }\end{array}$ & $\begin{array}{l}\text { Genotype } A T X N 2 \\
\text { (CAG repeats) }\end{array}$ & $\begin{array}{c}\text { Parental origin } \\
A T X N 2 \text { (CAG } \\
\text { repeats) }\end{array}$ & $\begin{array}{c}\text { Age of } \\
\text { death }\end{array}$ \\
\hline $\begin{array}{l}\text { Babovic et } \\
\text { al, } 1998\end{array}$ & $\begin{array}{l}\text { Child was born with neonatal hypotonia, at } 2 \text { wk progressive apnea, developmen- } \\
\text { tal delay, and dysphagia, Retinitis pigmentosa was noted at } 10 \text { mo. Next } 7 \text { mo, the } \\
\text { child remained hypotonic with increase feeding difficulties, dysphagia, and more } \\
\text { frequent apneas. The child continued to show slow progression of her neurological } \\
\text { symptoms and died from respiratory complications. }\end{array}$ & $\begin{array}{l}\text { New- } \\
\text { born }\end{array}$ & $23 / \sim 220$ & Father $22 / 43$ & $2 \mathrm{yr}$ \\
\hline $\begin{array}{l}\text { Mao et } \\
\text { al, } 2002\end{array}$ & $\begin{array}{l}\text { Male with severe hypotonia, } 2 \text { mo; poor head control, Poor visual alertness; no } \\
\text { retinopathy; intermittent esotropia. At } 7 \text { mo: marked cerebellar atrophy, delayed } \\
\text { myelination. EEG: hypsarrhythmia at } 14 \text { mo }\end{array}$ & $11 \mathrm{mo}$ & $22 / 230$ & Father 22/40 & $22 \mathrm{mo}$ \\
\hline $\begin{array}{l}\text { Mao et } \\
\text { al, } 2002\end{array}$ & $\begin{array}{l}\text { Male with hypotonia, developmental delay and dysphagia, Retinitis pigmentosa. } \\
\text { MRI At } 3 \text { mo: normal. EEG: normal at } 3 \text { mo. }\end{array}$ & $10 \mathrm{mo}$ & $22 / 400$ & Father 22/43 & $2 \mathrm{yr}$ \\
\hline $\begin{array}{l}\text { Mao et } \\
\text { al, } 2002\end{array}$ & $\begin{array}{l}\text { Male with encephalopathy, chronic seizures, hypertonic extremities, chronic sei- } \\
\text { zures, axial, hypotonia, severe developmental retardation, microcephaly, short } \\
\text { stature, Visual impairment, In MRI Cerebellar atrophy, EEG: hypsarrhythmia }\end{array}$ & $3 \mathrm{mo}$ & $22 / 350$ & Father $22 / 40$ & NR \\
\hline $\begin{array}{l}\text { Mao et } \\
a l, 2002\end{array}$ & $\begin{array}{l}\text { Male with hypotonia, visual impairment, delayed motor development, nystag- } \\
\text { mus, dysconjugated, gaze, convergent, strabismus, pigmentary, retinopathy, MRI } \\
\text { at } 7 \text { mo: mild diffuse parenchymal loss, delayed myelination. At } 18 \text { mo: moderate } \\
\text { diffuse cerebellar atrophy, EEG repetitive discharges of sharp and slow wave ac- } \\
\text { tivity; pronounced slowing of EEG }\end{array}$ & $10 \mathrm{mo}$ & $22 / 500$ & Mother 22/45 & NR \\
\hline $\begin{array}{l}\text { Moretti et } \\
\text { al, } 2004\end{array}$ & $\begin{array}{l}\text { A male child initially presented with abnormal eye movements at age } 2 \text { mo, devel- } \\
\text { opmental delay at } 6 \text { mo. At the } 7 \mathrm{yr} \text { he developed ataxia and cognitive impair- } \\
\text { ment, and subsequently manifested dysphagia and incontinence. At age } 11 \mathrm{yr} \text {, he } \\
\text { had bilateral external ophthalmoplegia, ataxic dysarthria, dysmetria and tremor in } \\
\text { the upper extremities, and marked gait ataxia, and brain MRI demonstrated cere- } \\
\text { bellar, brainstem, and cerebral atrophy. }\end{array}$ & $2 \mathrm{mo}$ & $22 / 62$ & $\begin{array}{l}\text { Mother } 22 / 22 \text {. } \\
\text { Father non } \\
\text { tested. }\end{array}$ & NR \\
\hline $\begin{array}{l}\text { Dirik et } \\
a l, 2007\end{array}$ & $\begin{array}{l}\text { A female baby appeared completely normal at birth. At the age of } 5 \mathrm{yr} \text {, began } \\
\text { ataxia, dysarthria, head titubation, and cognitive deficits. At age } 8 \mathrm{yr} \text {, she was not } \\
\text { able to walk because of severe ataxia. She also had drooling, feeding prob- } \\
\text { lems, and bladder dysfunction. Severe truncal } \\
\text { ataxia, tremor, dysarthria, dysmetria, hyporeflexia, and slow saccades. }\end{array}$ & $5 \mathrm{yr}$ & $22 / 70$ & Father $22 / 40$ & NR \\
\hline $\begin{array}{l}\text { Abdel et } \\
\text { al., } 2008\end{array}$ & $\begin{array}{l}\text { Proband male starting as early as } 2 \text { yr old with progressive extrapyramidal mani- } \\
\text { festations, slow eye movements and cognitive impairment. The patient lost all } \\
\text { cognitive functions, had persistent dystonic, vasomotor instability, and dysphagia } \\
\text { and died at the age of } 7 \text { yr. The early neurological symptoms included } \\
\text { choreoathetotic, myoclonic jerk, gait difficulty, and emotional liabil- } \\
\text { ity, ataxia, incoordination, dysarthria, mild dementia and slow eye saccades pre- } \\
\text { dominated. Peripheral neuropathy, polyphagia and obesity. }\end{array}$ & $24 \mathrm{mo}$ & $22 / 69$ to 75 & Father 22/ 39 & $7 \mathrm{yr}$ \\
\hline $\begin{array}{l}\text { Paciorkowski } \\
\text { et al, } 2011\end{array}$ & $\begin{array}{l}\text { This infant girl presented with apnea at } 2 \mathrm{wk} \text {, occipital-frontal circumference was } 3 \\
\text { SD at } 10 \text { mo of age, Retinitis pigmentosa, developed infantile spasms at } 16 \text { mo, with } \\
\text { hypsarrhythmia on EEG. She died at two yr old from respiratory complications. }\end{array}$ & $2 \mathrm{wk}$ & $22 / 220$ & Mother 22/43 & $2 \mathrm{yr}$ \\
\hline $\begin{array}{l}\text { Paciorkowski } \\
\text { et al, } 2011\end{array}$ & $\begin{array}{l}\text { This infant girl presented hypotonia at } 6 \text { mo, optic nerve atrophy, cerebellar atro- } \\
\text { phy and delayed myelination and enlarged lateral ventricles, and obvious cerebel- } \\
\text { lar and brainstem atrophy. At } 14 \text { mo she developed infantile spasms with } \\
\text { hypsarrhythmia. She had relative microcephaly and optic nerve atrophy. Death at } \\
22 \text { mo due to aspiration pneumonia. }\end{array}$ & $6 \mathrm{mo}$ & $22 / 200$ & Father $22 / 42$ & $22 \mathrm{mo}$ \\
\hline $\begin{array}{l}\text { Paciorkowski } \\
\text { et al, } 2011\end{array}$ & $\begin{array}{l}\text { This infant boy presented at } 3 \text { mo with focal seizures. At } 10 \text { mo he developed in- } \\
\text { fantile spasms with hypsarrhythmia. Brain MRI at } 10 \text { mo showed prominent sulci } \\
\text { frontally, enlargement of the lateral and third ventricles, and an atrophic-appearing } \\
\text { cerebellum. At } 12 \text { mo he was microcephaly, diagnosed cortical visual impairment. } \\
\text { He had impaired swallowing and autonomic instability. He died at } 13 \text { mo. }\end{array}$ & $3 \mathrm{mo}$ & $22 />200$ & Mother 22/45 & $13 \mathrm{mo}$ \\
\hline $\begin{array}{l}\text { Paciorkowski } \\
\text { et al, } 2011\end{array}$ & $\begin{array}{l}\text { This infant girl presented with loss of head control and poor visual fixation at } 3 \\
\text { mo and at } 5 \text { mo she had myoclonic seizures. At } 17 \text { mo EEG showed } \\
\text { high-amplitude bursts of slow waves with polyspikes reminiscent of } \\
\text { hypsarrhythmia. Brain MRI at } 6 \text { mo showed diffuse parenchymal volume loss and } \\
\text { delayed myelination. She was microcephaly and by } 21 \text { mo with minimal visual in- } \\
\text { teraction and retinitis pigmentosa. She died at } 32 \text { mo. }\end{array}$ & $3 \mathrm{mo}$ & $22 / 500$ & Father 22/40 & $32 \mathrm{mo}$ \\
\hline Paciorkowski & This infant girl had global developmental delay in infancy, and microcephaly. At & $48 \mathrm{mo}$ & $22 / 750$ & Father $22 / 40$ & NR \\
\hline
\end{tabular}


Table 1 cont.

\begin{tabular}{|c|c|c|c|c|c|}
\hline Reference & Main findings & $\begin{array}{c}\text { Age of } \\
\text { onset }\end{array}$ & $\begin{array}{c}\text { Genotype } A T X N 2 \\
\text { (CAG repeats) }\end{array}$ & $\begin{array}{l}\text { Parental origin } \\
A T X N 2 \text { (CAG } \\
\text { repeats) }\end{array}$ & $\begin{array}{c}\text { Age of } \\
\text { death }\end{array}$ \\
\hline $\begin{array}{l}\text { Paciorkowski } \\
\text { et al, } 2011\end{array}$ & $\begin{array}{l}\text { This infant girl presented at } 2 \text { mo with poor head control and lack of visual fixa- } \\
\text { tion, at } 7 \text { mo she had tonic seizures, EEG at } 14 \text { mo showed multifocal epileptiform } \\
\text { discharges. At } 12 \text { mo with retinitis pigmentosa. Brain MRI at } 12 \text { months showed } \\
\text { mild cerebellar atrophy. The patient died after a neurodegenerative course. Patho- } \\
\text { logic examination of the cerebellum showed profound loss of Purkinje and granu- } \\
\text { lar neurons with severe attenuation of the molecular layer. }\end{array}$ & $2 \mathrm{mo}$ & $22 / 300$ & Father 22/43 & NR \\
\hline $\begin{array}{l}\text { Di Fabio et } \\
a l, 2012\end{array}$ & $\begin{array}{l}\text { A girl who presented with facial dysmorphism, dystonic features, developmental } \\
\text { delay, and retinitis pigmentosa; and associated with developmental delay and } \\
\text { retinitis pigmentosa in early childhood. }\end{array}$ & $12 \mathrm{mo}$ & $22 / 92$ & Father 22/51 & \\
\hline $\begin{array}{l}\text { Vinther-Jens } \\
\text { en } \text { et } \\
\text { al., } 2013\end{array}$ & $\begin{array}{l}\text { Male and his daughter aged } 6 \text { mo, she was referred to a local hospital with uncoor- } \\
\text { dinated eye movement with parallel eye axes, lack of head control and hypotonia } \\
\text { in the upper extremities and the trunk, generalized myoclonic jerks and athetoid } \\
\text { movements. EEG showed bilateral spike foci in the frontal and parietal regions. At } \\
\text { the age of } 9 \text { mo, brain MRI was normal except for a relatively large cerebel- } \\
\text { lum-medullary cistern. At the } 13 \text { mo, she had motor improvement, dyskinesia, de- } \\
\text { layed visual development, pallor of the optic nerves and hyperpigmentation of } \\
\text { dystrophic retina. At the } 17 \text { mo, generalized edema and proteinuria, and minimal } \\
\text { change glomerulonephritis. She died of sepsis and multi-organ failure } 2 \text { mo later. } \\
\text { His brother had gait disturbances, and his daughter had died from multi-organ fail- } \\
\text { ure at age } 19 \text { mo. }\end{array}$ & $6 \mathrm{mo}$ & $\begin{array}{l}\text { Daughter } 124 \\
\text { CAG re- } \\
\text { peats, Brother } \\
\text { single-cell } \\
\text { sperm in 92, in } \\
\text { genomic DNA } \\
45 \text { CAG repeats }\end{array}$ & Father 22/45 & $19 \mathrm{mo}$ \\
\hline $\begin{array}{l}\text { Singh et } \\
a l, 2014\end{array}$ & $\begin{array}{l}\text { A } 10 \text {-month male child was referred to regression of milestones since } 6 \text { mo of age. } \\
\text { Here was no obvious dysmorphology, decreased muscle tone, inability to roll in } \\
\text { his bed, and decreased tendon reflexes in all limbs and retinitis pigmentosa. MRI } \\
\text { (at age of } 10 \text { mo) showed a markedly small cerebellum and vermis with associated } \\
\text { atrophy involving the brainstem and both cerebral hemispheres. There was mas- } \\
\text { sive enlargement of the ventricles and enlarged infratentorial subarachnoid spaces. } \\
\text { Additionally, diffuse T2 hyperintensity was observed within the periventricular } \\
\text { white matter. Arachnoid cysts within the posterior fossa and right anterior tempo- } \\
\text { ral region were incidental findings. }\end{array}$ & $6 \mathrm{mo}$ & $22 / * 320$ & Father 22/47 & NR \\
\hline $\begin{array}{l}\text { Avelino et } \\
\text { al., } 2014\end{array}$ & $\begin{array}{l}\text { A 1-year-old Brazilian girl presented the phenotype of very early-onset SCA2 } \\
\text { (neonatal form) encephalopathy, with hypotonia, choreic movements, dystonia } \\
\text { with dystonic jerks, seizures, and retinitis, motor developmental delay. During the } \\
\text { neonatal period (first mo), she presented hypotonia, dysphagia, and frequent } \\
\text { gastroesophageal reflux. Tonic seizures, hypotonic with increased feeding diffi- } \\
\text { culties, and choreic movements and dystonia with dystonic jerks. Decreased tonus } \\
\text { and global decreased tendon reflexes. Visual fixation was poor and erratic } \\
\text { eye, ophthalmoplegia were observed. Fundoscopy disclosed abnormal retina, with } \\
\text { white dots, suggesting retinitis punctata albescens. Brain MRI showed marked } \\
\text { cerebellar and brainstem atrophy and mild delayed myelination. }\end{array}$ & $\begin{array}{l}\text { New- } \\
\text { born }\end{array}$ & $22 / 104$ & $\begin{array}{l}\text { Father Non } \\
\text { determinated }\end{array}$ & NR \\
\hline
\end{tabular}

$\mathrm{NR}$ - not recorded; mo- months, yr- years, wk-weeks.

massive expansion of more than $884 \mathrm{CAG}$ repeats in exon 1 of ATXN2. Massive expansions in the SCA2 are considered above one hundred repeats, longer are associated with an early onset age, and also are related with severe clinical findings (Antenora et al., 2017). Certainly, the present case started with symptoms since birth and severe neurological deterioration and a genotype with a longer allele, compared with other neonatal cases (Babovic et al., 1998; Dirik et al., 2007).

So, the range in 19 reported cases with SCA2 with age of onset in childhood was 0-48 months, which were carriers of the heterozygous genotype $(22 / \mathrm{X})$, in which $\mathrm{X}$ corresponds to an allele with abnormal expansion repeats with an average range of 62-841 repeats (Table 1) (Babovic et al., 1998; Mao et al., 2002; Moretti et al., 2004; Dirik et al., 2007; Abdel and Zaki, 2008; Paciorkowski et al., 2011; Di Fabio et al., 2012; Vinther-Jensen et al., 2013; Avelino et al., 2014; Singh et al., 2014).
Abnormal expansions in many trinucleotide expansion diseases are related with the anticipation phenomenon, resulting into longer mutant alleles of maternal origin. However, in infantile SCA2 with massive expansion, most of the reported cases with paternal origin contribute with a greater effect to the anticipation phenomenon (Table 1). On the other hand, there are three reported cases and the present one, with a maternal origin associated with a massive expansion (Mao et al., 2002; Paciorkowski et al., 2011; Trang et al., 2015).

There are two clinical prognostic severity markers in SCA2, which are saccades and dysphagia (Wadia et al., 1998). Dysphagia was reported in five cases with massive repeats, greater than 200 repeats (Babovic et al., 1998; Mao et al., 2002; Abdel and Zaki, 2008; Avelino et al., 2014). The present case presented dysphagia since birth.

Abnormalities in the electroencephalogram were frequent in infantile SCA2 cases reports, but the present case 
Table 2 - Clinical Epidemiology of the findings in infantile-onset SCA2.

\begin{tabular}{|c|c|c|c|}
\hline Clinical findings & Case & Mother & $\begin{array}{c}\text { Total reported } \\
\text { cases }\end{array}$ \\
\hline \multicolumn{4}{|l|}{ Neurological } \\
\hline Hypotonia & - & - & $8 / 19$ \\
\hline Tremor & - & - & $19 / 19$ \\
\hline Ataxia & + & + & $19 / 19$ \\
\hline Dysmetria & - & + & $19 / 19$ \\
\hline Dysdiadochokinesia & - & + & $19 / 20$ \\
\hline Dysarthria & + & + & $19 / 19$ \\
\hline $\begin{array}{l}\text { Neurological and cognitive deteriora- } \\
\text { tion }\end{array}$ & + & - & $3 / 19$ \\
\hline Saccades & - & - & $2 / 19$ \\
\hline $\begin{array}{l}\text { Abnormalities in the electroencephalo- } \\
\text { gram }\end{array}$ & - & + & $11 / 19$ \\
\hline \multicolumn{4}{|l|}{ MRI or CT } \\
\hline Cerebellar and brainstem atrophy & - & - & $12 / 19$ \\
\hline Olivopontocerebellar atrophy & + & + & $19 / 19$ \\
\hline $\begin{array}{l}\text { Atrophy involving both cerebral hemi- } \\
\text { spheres }\end{array}$ & - & - & $2 / 19$ \\
\hline $\begin{array}{l}\text { Massive enlargement of the ventricles } \\
\text { and enlarged infratentorial } \\
\text { subarachnoid spaces }\end{array}$ & - & - & $3 / 19$ \\
\hline $\begin{array}{l}\text { Arachnoid cysts within the posterior } \\
\text { fossa and right anteriortemporal re- } \\
\text { gion; relatively large cerebellum and } \\
\text { medullary cistern }\end{array}$ & - & - & $2 / 19$ \\
\hline $\begin{array}{l}\text { Diffuse T2 white matter signal abnor- } \\
\text { malities }\end{array}$ & - & - & $3 / 19$ \\
\hline $\begin{array}{l}\text { Cavitations of the parieto occipital } \\
\text { lobes and cortical and cerebellar vol- } \\
\text { ume loss }\end{array}$ & - & - & $1 / 19$ \\
\hline $\begin{array}{l}\text { Prominent sulci frontally and delayed } \\
\text { myelination }\end{array}$ & - & - & $1 / 19$ \\
\hline \multicolumn{4}{|l|}{ Ophthalmological } \\
\hline Visual alertness & - & - & $7 / 19$ \\
\hline
\end{tabular}

did not present abnormal patterns in the electroencephalogram or epilepsy with tonic seizures or myoclonic seizures (Mao et al., 2002; Paciorkowski et al., 2011; Vinther-Jensen et al., 2013; Singh et al., 2014). While cerebellar and brainstem atrophy were related with massive CAG expansions (> 200) in the ATXN2 gene (Babovic et al., 1998; Mao et al., 2002; Moretti et al., 2004; Dirik et al., 2007; Paciorkowski et al., 2011; Magaña et al., 2008; Vinther-Jensen et al., 2013; Singh et al., 2014; Avelino et al., 2014). A case whose brain at 5 years 10 months showed diffuse T2 white matter signal abnormalities, with cavitations of the parieto-occipital lobes and cortical and cerebellar volume loss, was found carrier of a genotype 22/ 750 (Paciorkowski et al., 2011). In the present case the CT brain scan revealed mild pontine atrophy, moderate cerebellar atrophy, with longer repeats $22 / \sim 841$. This indicates that the severity of the damage to the brain structures not only depend of the ATXN2 VNTR expansion, but may influence

\begin{tabular}{|c|c|c|c|}
\hline Clinical findings & Case & Mother & $\begin{array}{c}\text { Total reported } \\
\text { cases }\end{array}$ \\
\hline $\begin{array}{l}\text { Intermittent esotropia; Visual impair- } \\
\text { ment }\end{array}$ & - & - & $2 / 19$ \\
\hline Nystagmus & + & - & $3 / 19$ \\
\hline $\begin{array}{l}\text { Dysconjugated gaze, convergent stra- } \\
\text { bismus, ophthalmoplegia }\end{array}$ & - & - & $2 / 19$ \\
\hline Atrophy of the optic nerve & - & - & $2 / 19$ \\
\hline $\begin{array}{l}\text { Incoordinated eye movement with par- } \\
\text { allel eye axes }\end{array}$ & - & - & $1 / 19$ \\
\hline Retinitis pigmentosa & - & - & $11 / 19$ \\
\hline Retinitis punctata albescens & - & - & $1 / 19$ \\
\hline \multicolumn{4}{|l|}{ Miscellaneous } \\
\hline Microcephaly & - & - & $4 / 19$ \\
\hline Facial dysmorphism & - & - & $1 / 19$ \\
\hline Peripheral nerve affection & + & - & $1 / 19$ \\
\hline Polyphagia & - & - & $1 / 19$ \\
\hline Macrosomia & + & - & $1 / 19$ \\
\hline Pyramidal failure pathway & - & - & $1 / 19$ \\
\hline Generalized edema & - & - & $1 / 19$ \\
\hline Proteinuria & - & - & $1 / 19$ \\
\hline Minimal change glomerulonephritis & - & - & $1 / 19$ \\
\hline Problems or difficulty feeding & + & - & $2 / 19$ \\
\hline Urinary incontinence & + & - & $2 / 19$ \\
\hline Gastroesophageal reflux & - & - & $1 / 19$ \\
\hline Dysphagia & + & - & $5 / 19$ \\
\hline
\end{tabular}

Notes. Abnormalities in the electroencephalogram are considered hypsarrhythmia, repetive discharges of sharp and slow wave activit; pronounced slowing, infantile spasms with hypsarrhythmia, highamplitude bursts of slow waves with polyspikes reminiscent of hypsarrhythmia, multifocal epileptiform discharges, bilateral spike foci in the frontal and parietal regions and seizures. $\mathrm{MRI}=$ magnetic resonance imaging; $\mathrm{CT}=$ computed tomography.

other genes in which $A T X N 2$ forms a network, that corresponds to a new frontier of research in SCA2.

The present case presented gaze-evoked nystagmus without retinitis pigmentosa common in childhood SCA2 due to long CAG repeats in ATXN2 gene (see Table 2), greater than one hundred repeats (Babovic et al., 1998; Mao et al., 2002; Paciorkowski et al., 2011; Di Fabio et al., 2012; Vinther-Jensen et al., 2013; Avelino et al., 2014; Singh et al., 2014). In the literature has been reported massive expansion repeats (more than 750 repeats) in SCA2 with autonomic dysfunction, retinitis pigmentosa, and infantile spasms; the difference in the present case without retinitis pigmentosa, not only be explained by the age of onset, but also by the same molecular and allelic heterogeneity of retinitis, which is polygenic with different inheritance patterns (Fahim et al., 2018).

In patients with infantile SCA2, some craniofacial alterations were found, such as microcephaly in four cases and one case showed facial dysmorphism (Paciorkowski et al., 


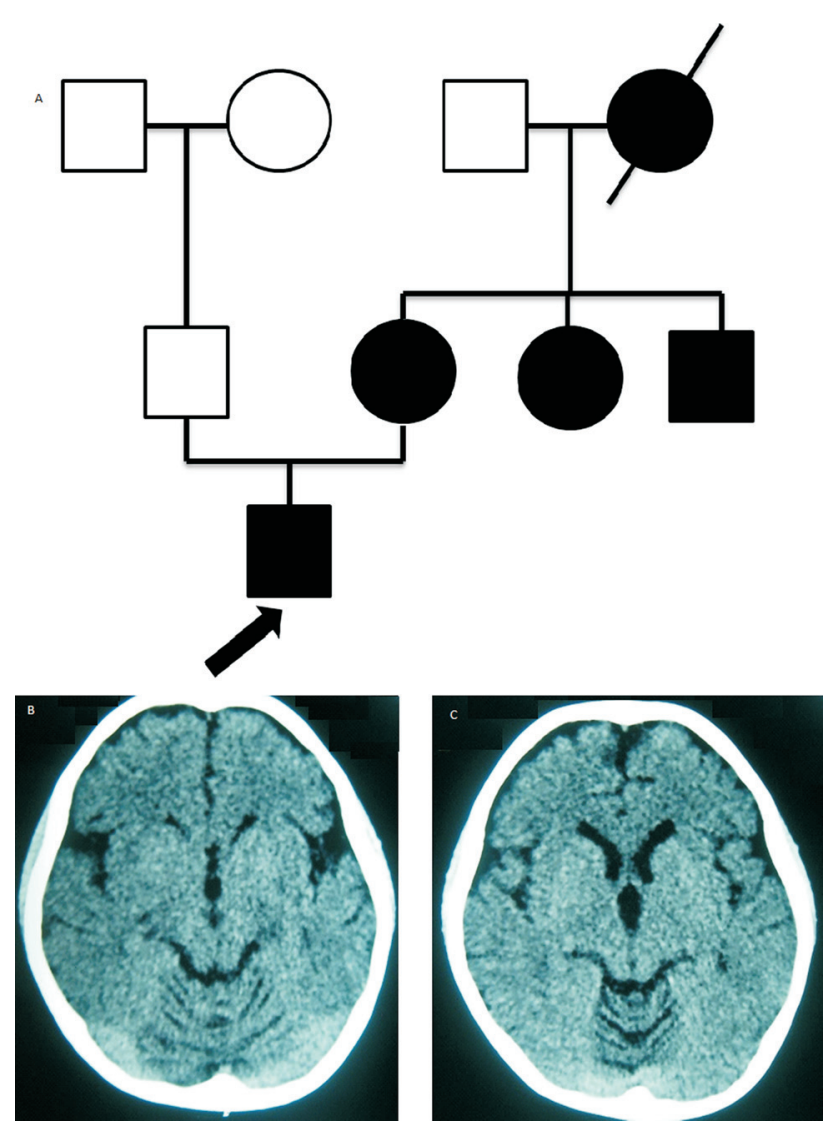

Figure 1 - A. Pedigree, arrow: the propositus. B-C., Propositus' CT brain scan showing mild pontine atrophy and moderate cerebellar atrophy

2011). These findings were not relevant in the present case, but it would be worthwhile to analyze them clinically in detail, because there is a possibility that they are not syndromic but may be related to an ATXN2 effect on cranial morphogenesis.

Peripheral nerve affection, polyphagia and obesity were striking manifestations in the middle stage of the disease, as well as generalized edema and proteinuria, and minimal change glomerulonephritis that were found in an isolated patient. This might support a previously suggested relationship between the ataxin-2 gene and body weight and insulin resistance, which is modulated by ataxin- 2 by the pathway of insulin by GRB2 and SRC (Flores-Alvarado et al., 2016; Guzmán-López et al., 2018; Ramirez-Garcia et al., 2019). The two carriers of these phenotypic findings had an expanded alleles range between 90 and less than $130 \mathrm{CAG}$ repeats, which corroborates the participation of ataxin-2 gene in the development of metabolic syndrome traits (Flores-Alvarado et al., 2016; Ramirez-Garcia et al., 2019). However, our tester has the highest repeating range in the literature, and has not developed any of these findings, which suggests that there are other genes that can modify the SCA2 phenotype, especially in the case of children (Ramírez-Garcia et al., 2011; Trang et al., 2015).

In conclusion, the present report describes a child with infantile SCA2 with a massive expansion of CAG

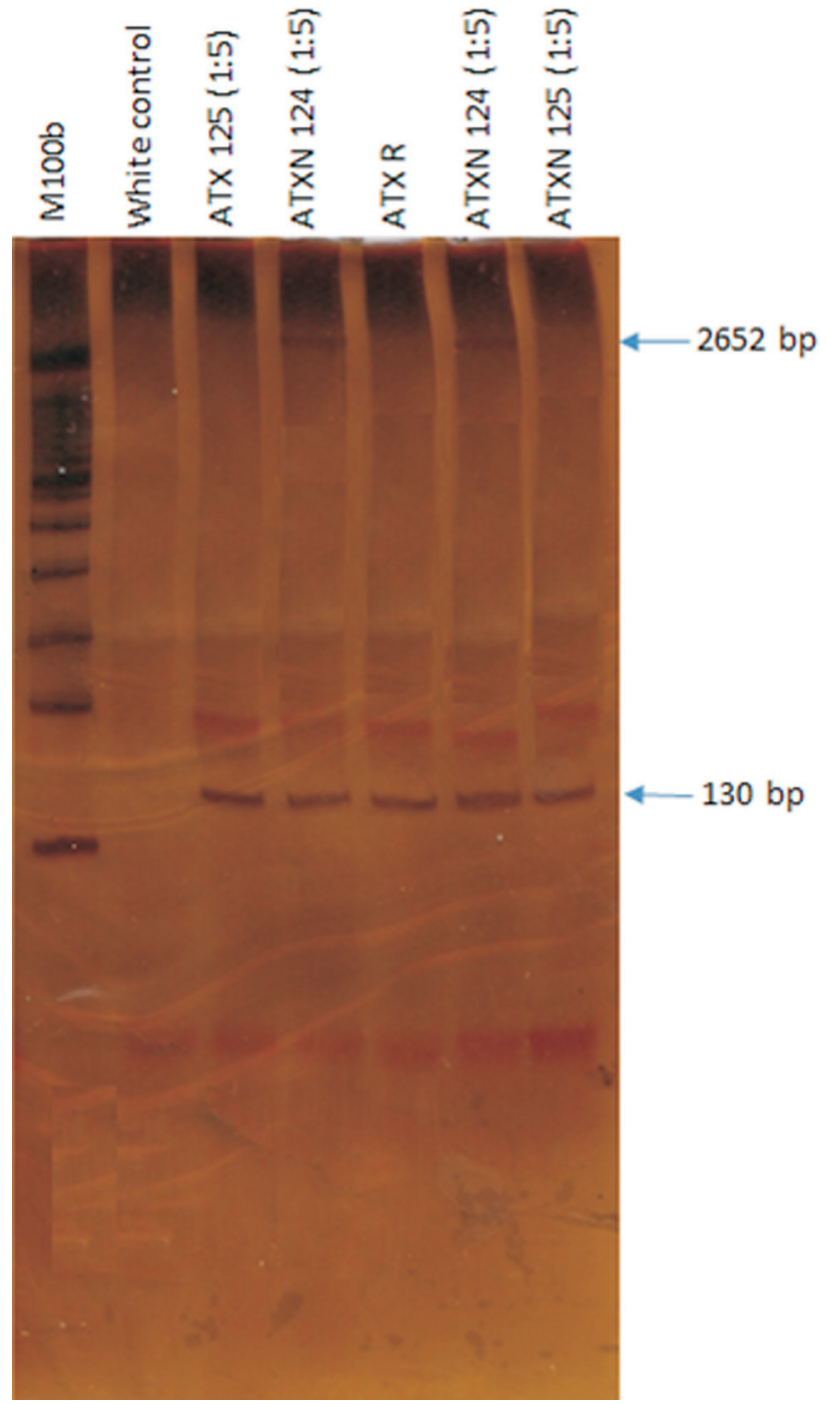

Figure 2 - PAGE gel showing in the $4^{\text {th }}$ and $6^{\text {th }}$ lanes the extreme CAG repeats expansion $\sim 884$.

trinucleotides of the ATXN2 gene reported up to date in the literature, which resulted in a very early onset of clinical findings, since birth, and whose phenotype mainly corresponds to the severe affection of the central and peripheral nervous system. Also, this is the first childhood case in a Mexican and Latin-American population. The review of the literature of 18 cases of infantile SCA2 and the comparison with the present case shows a great clinical and molecular heterogeneity, which does not always correlate with the greater number of CAG repeats of the ATXN2 gene. The most frequent clinical signs were hypsarrhythmia, hypotonia, pigmentosa retinitis, cerebellar atrophy, as well as middle brain and lengthening of the ventricular system. The range of CAG repeats ranged between 69-884 repeats; however, longer repeats have more severe phenotypes. 


\section{Acknowledgments}

This research was supported by Grants PROCOFINSEP-PRODEP and Marcagen S.A. de C.V. For the professional editing of English language by Brieden Coy Marriot BA, chief of the language center of Sierra Sur University. We would like to thank Hector V. Ortega MD, Adjunct Professor of Neurosurgery research, Adjunct Professor of Biomedical Engineering, Thomas Jefferson University, for scientific advice.

\section{Conflict of Interest}

The authors declare that there is no conflict of interest.

\section{Author Contributions}

JSC wrote the manuscript, conceived and designed the study, SARG conducted experiments, wrote the manuscript, GCS analyzed data and was responsible of the management clinical of the patient, SAGR conducted experiments, VV conducted experiments, DMSG analyzed data, JEGO analyzed data, and DGC conceived and designed the study and wrote the manuscript. All authors read and approved the final version.

\section{References}

Abdel AA and Zaki MS (2008) Spinocerebellar ataxia type 2 (SCA2) in an an Egyptian family presenting with polyphagia and marked CAG expansion in infancy. J Neurol 55:413-419.

Antenora A, Rinaldi C, Roca A, Pane C, Lieto M, Saccá F, Peluso S, De Michele G and Filla A (2017) The multiple faces of spinocerebellar ataxia type 2. Ann Clin Transl Neurol 10:687-695.

Avelino MA, Pedroso L, Orlacchio A, Barsottini OGP and Masruha MR (2014) Neonatal SCA2 presenting with choreic movements and dystonia with dystonic jerk, retinitis, seizures and hypotonia. Mov Disord Clin Pract 1:252-254.

Babovic VD, Snow K, Patterson MC and Michels VV (1998) Spinocerebellar ataxia type 2 (SCA 2) in an infant with extreme CAG repeat expansion. Am J Med Genet 79:383-387

Choudhry S, Mukerji M, Srivastava AK, Jain S and Brahmachari SK (2001) CAG repeat instability at SCA2 locus: anchoring CAA interruptions and linked single nucleotide polymorphisms. Hum Mol Genet 10:2437-2446.

Di Fabio R, Santorelli F, Bertini E, Balestri M, Cursi L, Tessa A, Pierelli F and Casali C (2012) Infantile childhood onset of spinocerebellar ataxia type 2. Cerebellum 11:526-530.

Dirik E, Yis U, Basak N, Soydan E, Hüdaoglu O and Ozgönül F (2007) Spinocerebellar ataxia type 2 in a Turkish family. J Child Neurol 22:891-894.

Flores-Alvarado LJ, Dávalos-Rodríguez NO, García-Cruz D, Madrigal-Ruiz PM, Ruiz-Mejía R, Aguilar-Aldrete ME and Ramirez-Garcia SA (2016) (CAG)n polymorphism of the ATXN2 gene, a new marker of susceptibility for type 2 diabetes mellitus. Rev Panam Salud Publica 40:318-324.

Guzmán-López R, García-Cruz D, Magallanes-Ordoñez JJ, Siliceo-Murrieta J, Dávalos-Rodríguez N, Ruiz-Mejía R,
Madrigal-Ruiz PM, Cruz-Bastida JM, Cruz-Bastida JS, Duque-Bautista H et al. (2018) Childhood obesity, insulin resistance and the polymorphism (CAG)n of the ATXN2 gene. Rev Med MD 9:134-139.

Magaña JJ, Vergara MD, Sierra-Martínez M, García-Jiménez E, Rodríguez-Antonio F, del Rocío Gómez M, Valdés-Flores M and Cisneros B (2008) Molecular analysis of the CAG repeat among patients with Type- 2 spinocerebellar ataxia in the Mexican population. Gac Med Mex 144:413-418.

Mao R, Aylsworth AS, Potter N, Wilson WG, Breningstall G, Wick MJ, Babovic-Vuksanovic D, Nance M, Patterson MC, Gomez $\mathrm{CM}$ et al. (2002) Childhood-onset ataxia: testing for large CAG-repeats in SCA2 and SCA7. Am J Med Genet 110:338-345.

Moretti P, Blazo M, Garcia L, Armstrong D, Lewis RA, Roa B and Scaglia F (2004) Spinocerebellar ataxia type 2 (SCA2) presenting with ophthalmoplegia and developmental delay in infancy. Am J Med Genet A 124A:392-396.

Paciorkowski AR, Shafrir Y, Hrivnak J, Patterson MC, Tennison MB, Clark HB and Gomez CM (2011) Massive expansion of SCA2 with autonomic dysfunction, retinitis pigmentosa, and infantile spasms. Neurology 77:1055-1060.

Ramirez-Garcia SA, Sánchez-Corona J, Ortega-Pacheco D, Ramírez-Bohórquez E and García-Cruz D (2019) Ataxina-2, nuevo blanco en enfermedades genéticas complejas. Gac Med Mex 155:58-62.

Ramírez-Garcia SA, Volpini V, Castañeda-Cisneros G, Sánchez-Corona J, Morán-Moguel MC, Gutierrez- Rubio S and Garcia-Cruz D (2011) Expansión del repetido (CAG)n del gen ATXN2 en pacientes del Noroccidente de Mexico con ataxia espinocerebelosa y la evidencia de cinco genes modificadores. Rev Arch Cien 3:28.

Singh A, Faruq M, Mukerji M, Dwivedi MK, Pruthi S and Kapoor S (2014) Infantile onset spinocerebellar ataxia 2 (SCA2): a clinical report with review of previous cases. J Child Neurol 29:139-144

Trang H, Stanley SY, Thorner P, Faghfoury H, Schulze A, Hawkins C, Pearson CE and Yoon G (2015) Massive CAG repeat expansion and somatic instability in maternally transmitted infantile spinocerebellar ataxia type 7. JAMA Neurol 72:219-23.

Vinther-Jensen T, Ek J, Duno M, Skovby F, Hjermind LE, Nielsen JE and Nielsen TT (2013) Germline CAG repeat instability causes extreme CAG repeat expansion with infantile-onset spinocerebellar ataxia type 2. Eur J Hum Genet 21:626.

Wadia N, Pang J, Desai J, Mankodi A, Desai M and Chamberlain S (1998) A clinicogenetic analysis of six Indian spinocerebellar ataxia (SCA2) pedigrees. The significance of slow saccades in diagnosis. Brain 121:2341-2355.

\section{Internet Resources}

Fahim AT, Daiger SP and Weleber RG, Nonsyndromic Retinitis Pigmentosa, https://www.ncbi.nlm.nih.gov/books/NBK1417/.

Associate Editor: Angela M. Vianna-Morgante.

License information: This is an open-access article distributed under the terms of the Creative Commons Attribution License (type CC-BY), which permits unrestricted use, distribution and reproduction in any medium, provided the original article is properly cited. 